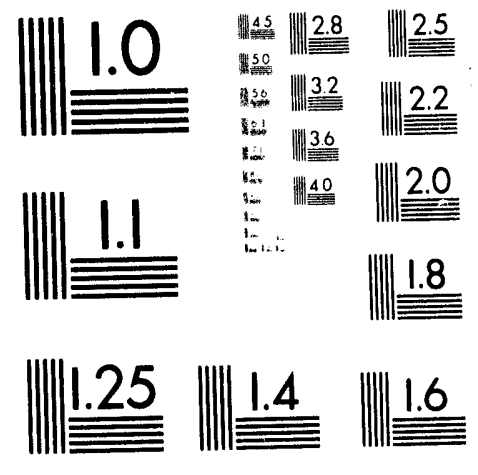



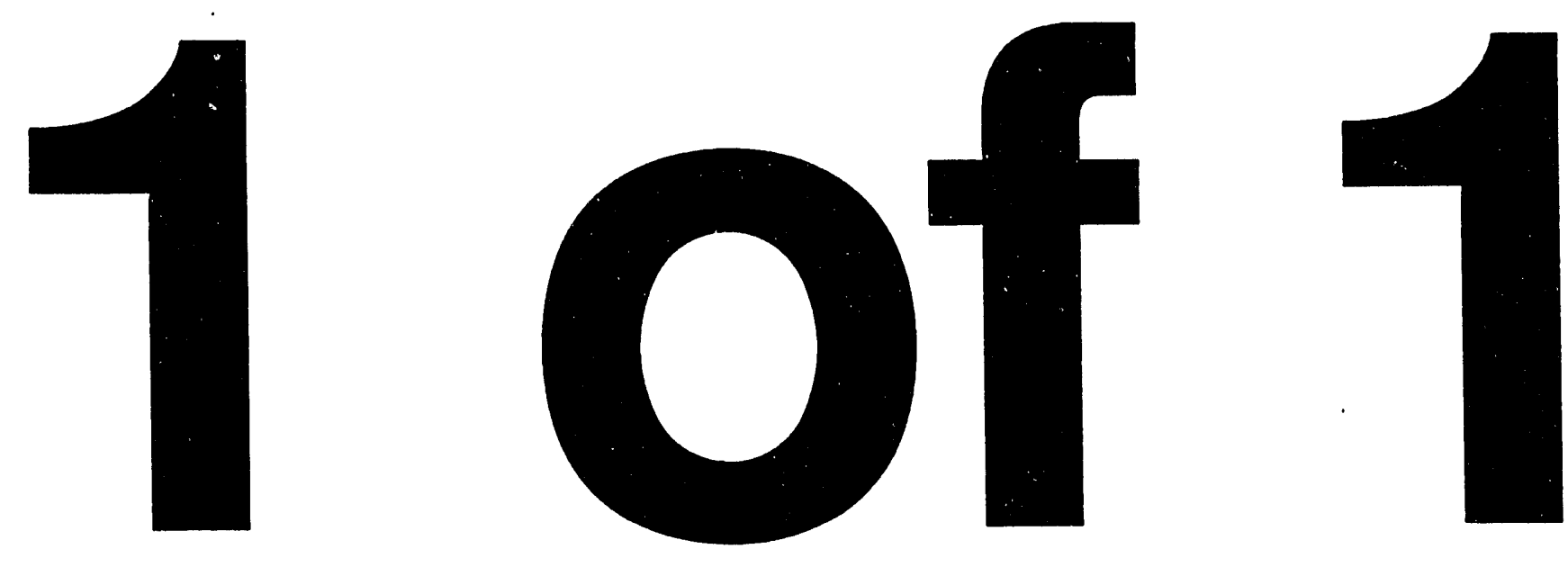


\section{IN SITU SPECTROSCOPIC APPLICATIONS TO THE STUDY OF RECHARGEABLE LITHIUM BATTERIES}

Final Report

August 1993

by

\section{Rachael Barbour \\ Sunghyun Kim \\ Donald (Sandy) Tryk \\ Daniel A. Scherson}

Department of Chemistry

Case Western Reserve University

Cleveland, Ohio 44106-7078

for

Energy \& Environment Division

Lawrence Berkeley Laboratory

Berkeley, California 94720

This work was supported by the Assistant Secretary for Energy Efficiency and Renewable Energy, Office of Transportation Technologies, Electric and Hybrid Propulsion Division of the U.S. Department of Energy under Contract No. DE-AC03-76SF00098, Subcontract No. 4577910 with the Lawrence Berkeley Laboratory.

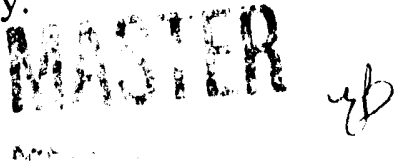


ABSTRACT .

I. INTRODUCTION.

II. ELECTROCHEMICAL AND IN SITU SPECTROSCOPIC CHARACTERIZATION OF LITHIUM/NON-AQUEOUS SOLVENT INTERFACES.

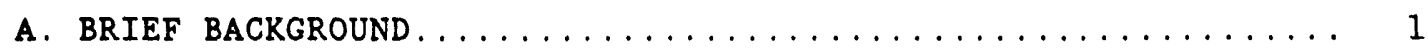

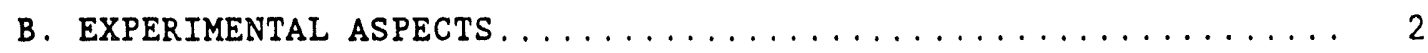

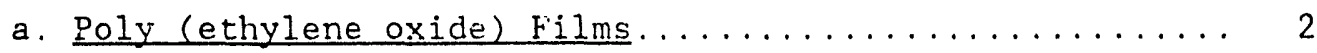

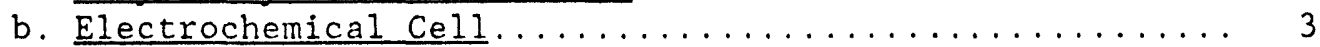

c. Syclic Voltammetry....................... 3

d. Spectroelectrochemical cell for in situ Attenuated Total Reflection Fourier Transform Infrared (ATR-FTIR) Spectroscopy of PEO/Lithium Interfaces at Elevated Temperatures........................ 3

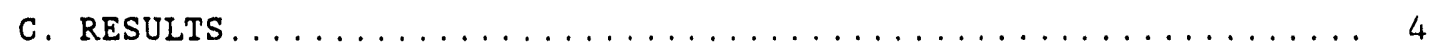

a. Electrochemical Characterization................ 4

1. Effects of Cycling..................... 4

2. Reproducibility....................... 4

3. Potential Window of Stability of PEO.......... 5

4. Effect of Plasticizers: Propylene Carbonate....... 5

b. In situ Attenuated Total Reflection Fourier Transform Infrared (ATR-FTIR) Spectroscopy ...............

III. IN SITU Fe K-EDGE X-RAY ABSORPTION FINE STRUCTURE (XAFS) OF THE INTERCALATION OF IITHIUM INTO FeS 2 ELECTRODES ............. 5

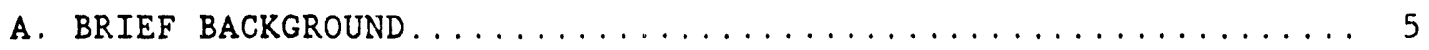

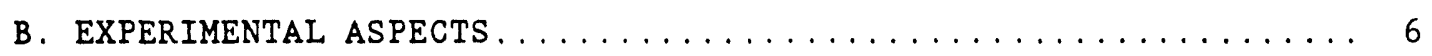

a. Spectroelectrochemical cel1 ................ 6

b. Electrochemical Measurements ................ 6

c. XAFS Measurements ..................... 7

C. $\operatorname{RESULTS} \ldots \ldots \ldots \ldots \ldots \ldots \ldots \ldots \ldots \ldots \ldots \ldots \ldots \ldots$

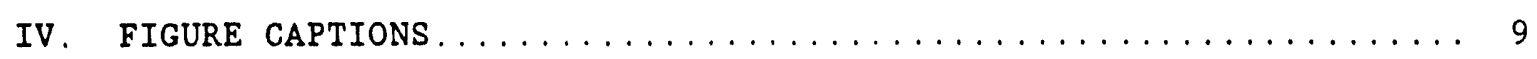

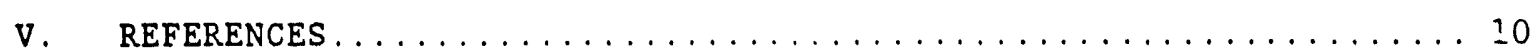




\section{ABSTRACT}

In situ attenuated total reflection Fourier transform infrared spectroscopy (ATR/FTIR) has been employed to examine the reactivity of lithium toward polyethylene oxide (PEO) at ca. $60^{\circ} \mathrm{C}$. Uncertainties regarding the cleanliness of the $\mathrm{Li}$ surfaces were ininimized by electrodepositing a film of metallic Li directly onto a thin layer of gold (ca. 60 A) vapor deposited on a Ge ATR optical element during the spectroscopic measurements. The ATR/FTIR features observed upon stripping the Li layer were consistent with the formation of alkoxide-type liojeties resulting from the Li-induced cleavage of the ether-type functionalities.

Electronic and structural aspects of the electrochemical insertion of lithium from non-aqueous electrolytes into $\mathrm{FeS}_{2}$ have been investigated using in situ $F$ k-edge $X$-ray absorption fine structure (XAFS). The results obtained indicate that the incorporation of $\mathrm{Li}^{+}$in the pyrite lattice brings about a marked decrease in the amplitude of the extended XAFS (EXAFS) oscillations, particularly for shells associated with distant atoms and a rounding of the $X$-ray absorption near edge structure (XANES) region. An analysis of the tXiss spectra yielded a value for the $\mathrm{Fe}-$ $S$ distance of $2.29 \pm 0.02 \AA$. Un $t h i$ is bisis and additional in situ room temperature ${ }^{57} \mathrm{Fe}$ Mossbauer effect spuctroscopy data for the same system it has been proposed that the eltcriochinically formed material involves a highly disordered (possibly anorphous) form of Fel-x (with Lit counterbalancing the charge). 


\section{INTRODUCTION}

Energy storage devices can provide an efficient and reliable means of decoupling energy demand and supply in terms of both the nature and availability of primary sources. Systems based on electrical energy, such as rechargeable batteries, offer a high degree of versatility in that the conversion to other forms of energy such as thermal, mechanical and chemical can be effected with relative ease. 1

The development of durable, low-cost, rechargeable batteries with high specific energy and power characteristics will have a profound impact on vehicular propulsion by providing a pollution-free energy source that could replace hydrocarbon-based fuels. Electric cars, however, must display high acceleration, long range and moderate cost to become viable commercial alternatives to conventional gas-fueled vehicles. A number of battery systems have been identified that satisfy, in varying degrees, some of these requirements, including lead-acid, $\mathrm{Zn} / \mathrm{Ni}$ oxide, $\mathrm{Fe} / \mathrm{Ni}$ oxide, $\mathrm{Zn} / \mathrm{Br}_{2}$, $\mathrm{Na} / \mathrm{sulfur}, \mathrm{Li} / \mathrm{FeS}$ and $\mathrm{Li}_{/} / \mathrm{FeS}_{2}$. Of crucial importance to the further optimization of these and other systems is a more precise identification of the factors that control their cycle life characteristics.

The primary objective of the research conducted during the last performance period is to elucidate basic chemical and structural aspects of electrode materials that exhibit promising characteristics for use in lithium-based rechargeable batteries. Insight into these issues was achieved using primarily two in situ spectroscopic probes:

i) In situ Fourier Transform Infrared (FTIR) for studies of the Lithium-Solid Polymer Electrolyte (Li/SPE) Interface

ii) In situ X-ray Absorption Fine Structure (XAFS) to examine the $\mathrm{Li}_{\mathrm{x}} \mathrm{FeS}_{2}$ Electrode in Non-Aqueous Liquid Solvents

\section{ELECTROCHEMICAL AND IN SITU SPECTROSCOPIC CHARACTERIZATION OF LITHIUM/ SOLID POLYMER ELECTROLYTE INTERFACES}

\section{A. BRIEF BACKGROUND}

Lithium is expected to find widespread use in high-energy-density batteries because of its very negative standard reduction potential and light equivalent weight. The operation of lithium electrodes relies on the presence of a surface film that protects the underlying metal from further corrosion and at the same time provides a medium that can sustain facile lithium-ion transport. $2-25$ This film forms spontaneously upon exposing air oxidized (or bare) Li surfaces to the electrolyte and is believed to contain decomposition products originating from both the solvent and the salt (in addition to those derived from atmospheric gases).

Technological advances over the past decade have led to the commercialization of primary lithium-based batteries, for which the electrochemical reaction at the anode is $\mathrm{Li}$ dissolution. Attempts to reverse the process (for example, by electrically recharging the cell) and thus reconstitute the metal electrode, have met with only limited success in the sense that the amount of inetal recovered is always less than that originally dissolved. This low cycling efficiency represents perhaps the single most 
serious obstacle to the developinent of efficient lithium-based rechargeable batteries. Most of these problems appear to stem from changes in the morr ology of the metal induced by dissolution (discharge) and deposition (charging) cycles. There exists considerable evidence, for example, that under certain conditions dendrites or other types of fibrillar deposits are formed during deposition which penetrate through the protective layer and react with the electrolyte.

Much of the attention in recent years has focused on lithium-ion conducting solid polymer electrolytes, such as poly(ethylene oxide) (PEO).26-32 These materials offer several advantages over liquid solvents in terms of ease of handling and formability and much lower reactivity toward metallic lithium. These factors are expected to simplify the design and construction of actual devices and improve the performance of rechargeable cells.

Two polymer electrolyte materials appear to exhibit the most promising characteristics for Li-battery applications: highly pure, narrow molecular weight distribution PEO and 2-(2-methoxy-ethoxy-ethoxy)polyphosphazene (MEEP).28 Furthermore, the addition of low molecular weight organic compounds as plasticizers, such as propylene carbonate (PC), ethylene carbonate (EC) and poly (ethylene glycol dimethyl ether) 31,32 has been found to modify the rheological properties of the polymer leading to sizable gains in ionic conductivity.

One of the primary aims of this research program is to elucidate the nature of metallic lithium/solid polymer electrolyte interfaces. Work conducted at CWRU under the auspices of LBL/DOE provided for the first time spectroscopic evidence of the reactivity of PEO with clean metallic lithium, using in situ Fourier transform infrared spectroscopy (FT-IR) in the attenuated total reflection (ATR) mode. 33 It was concluded based on this study that the passive film formed at $\mathrm{Li} / \mathrm{PEO}$ interface at room temperature consists of PEO chains with lithium alkoxide end groups.

Attention during this past year has been focused on studies of the electrochemistry and reactivity of $\mathrm{Li}$ toward PEO, under conditions of direct relevance to technological applications. This section summarizes the most significant results obtained with cyclic voltanmetry and in situ Fourier transform infrared (FTIR) spectroscopy in the attenuated total reflection (ATR) mode. 34

\section{B. EXPERIMENTAL ASPECTS}

\section{a. Poly(ethylene oxide) Films}

Most of the operations involved in the preparaion of polyethylene oxide (PEO) films were performed in a Vacuum Atmospheres Dri-Train HE-493 dry box under an argon atmosphere using highly purified chemicals. Details regarding the casting and handling of PEO (Aldrich, $M W=600,000$ ) electrolyte films ( $\mathrm{Li}^{+}$/methylene-oxicle $=36$ ) of thicknesses on the order of tens of $\mu \mathrm{m}$ have been given in the literature ${ }^{33}$ and will not be repeated here. 


\section{b. Electrochemical Cell}

Cyclic voltammetry measurements were conducted in a slightly modified version of the sandwich-type cell described by Ichino et al. 33 Except where otherwise indicated, all electrochemical and spectroscopic experiments were carried out in a two-electrode configuration, with a single lithium foil being used as both counter and reference electrocle. The performance of this simple two-electrode arrangement was compared with that of a very similar three-electrode cell described below. Polypropylene (PP), a material impervious to attack by metallic $\mathrm{Li}$, was used as a gasket in all of the experiments. The cell was heated using Kapton-coated resistive elements. The temperature was monitored with a thermocouple (J-type) inserted into either a nickel coated aluminum plate or a stainless steel current collector for the lithium counter electrode. The temperature was controlled (within 3 to 4 degrees) using an Onega CN4400 controller.

Experiments involving a three-electrode arrangenent were performed by first electrodepositing lithium in situ (with the cell fully assembled) on a small, electrically isolated section of the working electrode to form the reference electrode. A number of successive potential sweeps into the $\mathrm{Li}$ bulk deposition range ( $0.3 \mathrm{~V}$ to $-1.0 \mathrm{~V}$ vs. $\mathrm{Li}$ counter electrode) were carried out until the peak currents becane reproducible. The open circuit potential of the reference electrode measured with respect to the Li counter electrode was found to be $+0.320 \mathrm{~V} \pm+0.005 \mathrm{~V}$. It might have been expected, however, that in the absence of concentration gradients no potential differences should be observed between the $L_{i}$ foil and the freshly electrodeposited lithium film. Such a potential shift is most likely derived from the formation of a Li/Au alloy, a process that proceeds quite rapidly even at room temperature.

Essentially identical voltammetric features were observed in the potential range of interest, -2 to $+3 \mathrm{~V}$ vs $\mathrm{Li} / \mathrm{Li}^{+}$for measurements performed in the two-, and in the three-electrode arrangenents (see Figure 1) using a $\mathrm{PEO} / \mathrm{PC} / \mathrm{LiClO}_{4} \mathrm{film}$. Note that the voltage axis in this figure has been shifted to account for the differences in the rest potential between the two reference electrodes.

\section{c. Cyclic Voltammetry}

Electrochemical measurements were conducted with a EG\&G PAR Potentiostat Model 273. Voltamnetric cycles were initiated at or near the open circuit potential (OCP) at a scan rate of $5 \mathrm{mV} / \mathrm{s}$.

d. Spectroelectrochemical Cell for in situ Attenuated Total Reflection Fourier Transform Infrared (ATR-FTIR) Spectroscopy of PEO/Lithium Interfaces at Elevated Temperatures

All experiments were conducted with a spectroelectrochemical cell similar in design to that described earlier by Ichino et al. 33 The use of a sealing material was in this case avoided in order to eliminate the possibility of contamination at the much higher temperatures involved in these studies $\left(>50^{\circ} \mathrm{C}\right)$. For the measurements reported herein, the (unsealed) cell was assembled in the glove box inside a specially designed isolation chamber. This enclosure consists of several precision-machined aluminum pieces, which upon assembly form a parallellepiped with two $\mathrm{KBr}$ windows 
attached to the parallel narrow plates, allowing the IR beam to enter the chamber, pass through the cell and exit toward the detector. Prior to the transfer (through air) to the FTIR spectrometer, the isolation chamber containing the operating cell was carefully tightened to avoid leaks. A piece of freshly scraped lithium was placed inside the chamber to act as a getter for adventitious gas contaminants and to serve as a primitive sensor to assess the quality of the gas surrounding the electrochemical cell during the spectroscopic measurements.

Spectra were recorded with the electrode polarized at selected potentials by scanning the voltage at $5 \mathrm{mV} / \mathrm{s}$ until the desired value was achieved. All spectroscopic data are displayed in terms of normalized potential difference (NPD) spectra using the spectrum obtained at the initial open circuit (prior to any external polarization) as a reference, where each spectrum represents the coaddition of 2000 interferometric scans.

\section{RESULTS}

\section{a. Electrochemical Characterization}

\section{Effects of Cycling}

Figure 2 shows a series of cyclic voltamnograms recorded at $5 \mathrm{mV} / \mathrm{s}$ in the region of $\mathrm{Li}$ bulk deposition and stripping on a ca. $2000 \AA$ gold electrode of an area of about $2.2 \mathrm{~cm}^{2}$, with a PEO-LiClO $\mathrm{film}_{4}$ (ca. $60 \mu \mathrm{m}$ thick, $36 \mathrm{CH}_{2} \mathrm{O} / \mathrm{Li}^{+}$) at $48^{\circ} \mathrm{C}$ using a $\mathrm{Li}$ counter/reference electrode. Cycles 1 through 4 (upper curves) were characterized by a monotonic increase in the charge associated with the deposition and stripping of metallic Li. As the cycling was continued (see cycles 24-26 in lower curves), a steady state voltammetry was achieved and maintained for over 100 cycles.

Integration of the anodic and cathodic features in Panel b, Fig. 2, yielded charges of 2930 and $2960 \pm 50 \mu \mathrm{C} / \mathrm{cm}^{2}$, which correspond to 14.2 and 14.3 morolayers of $\mathrm{Li}$, respectively. The fact that these charges are, within experimental error, identical, indicates that, under these steady state conditions, the consumption of lithium by irreversible processes is essentially negligible. This is an important indicator of the suitability of the system for rechargeable cells.

\section{Reproducibility}

A detailed inspection of a large number of cyclic voltammetry curves revealed that identical duplicate experiments often yielded substantially different quantitative results. 'Two factors were found to be responsible for these effects: the thickness of the polypropylene (PP) gasket material and the temperature distribution within the cell. After numerous tests, the optimal thickness for the PP gasket was found to be $37.5 \mu \mathrm{m}$, which is smaller than that of the PEO at room temperature, 55-60 $\mu \mathrm{m}$. Such a mismatch appears to be necessary in order to ensure good contact between the PEO film in the molten state and the electrode. Figure 3 shows results obtained in two independent duplicate runs for two sections of a $\mathrm{PEO} / \mathrm{LiClO} 4$ film at $55^{\circ} \mathrm{C}$ using these optimized conditions. 


\section{Potential Window of Stability of PEO}

Voltammetric scans in the positive direction for PEO-LiAsF 6 films obtained in the three electrode configuration dispiayed a pronounced increase in the current at a potential of about $3.5 \mathrm{~V}$ vs. $\mathrm{Li}^{+} \mathrm{Li}^{+}$(see Fig. 4). In contrast, no discernable background cathodic processes could be observed in scans in the negative direction even for potentials as negative as $-7 \mathrm{~V}$. The current plateau extending to $-6 \mathrm{~V}$ is typical of a diffusion controlled process in this type of cell geometry.

\section{Effect of Plasticizers: Propylene Carbonate}

In accordance with the results of other workers, large increases in the lithium deposition and stripping current peaks were observed for PEO films containing $P C$ as an additive. For example, the typical magnitude of the first stripping peak for $\mathrm{PEO}^{-\mathrm{LiClO}_{4}}$ (without $\mathrm{PC}$ ) was $-25 \mu \mathrm{A} / \mathrm{cm}^{2}$ and, for $\mathrm{PEO}-\mathrm{LiClO}_{4}$ (with PC), it was ca. $100 \mu \mathrm{A} / \mathrm{cm}^{2}$.

\section{b. In situ Attenuated Total Reflection Fourier Transform Infrared (ATR-FTIR) Spectroscopy}

The normalized potential difference (NPD) ATR-FTIR spectra of a $\mathrm{PEO} / \mathrm{LiClO}_{4}$ film at $48^{\circ} \mathrm{C}$ obtained at $0.5 \mathrm{~V}$ (Li UPD region), shown in curve a, Fig. 5, display two small negative-going bands at 1090 and $1110 \mathrm{~cm}^{-1}$. The first of these features is ascribed to the migration-induced depletion of perchlorate, induced most probably by underpotential deposition and/or lithium/Au alloy formation. The potential was then scanned to $0.0 \mathrm{~V}$ to deposit bulk lithium, and the cell was subsequently disconnected in order to mimic conditions found in charged batteries. The NPD ATR-FTIR spectrum, recorded after the voltage had stabilized at ca. $0.3 \mathrm{~V}$ (see curve b, Fig. $5)$, showed two broad bands at 1150 and $1200 \mathrm{~cm}-1$. These features have been ascribed to alkoxy-type $\mathrm{C}-0$ by Ichino et al. 33 , which would form following lithium attack of the PEO ether linkages i.e. $-\left(\mathrm{CH}_{2}\right)-0 \cdot\left(\mathrm{CH}_{2}\right)^{-}+\mathrm{Li} \cdot \ldots \cdot-\cdot>$ $-\left(\mathrm{CH}_{2}\right)-0-\mathrm{Li}^{+}+$other products. Spectra obtained at $+0.4 \mathrm{~V}$ after sweeping the potential to $-0.5 \mathrm{~V}$ revealed the presence of an additional band at $1100 \mathrm{~cm}^{-}$

1 , for which no assignment has yet been made.

\section{IN SITU Fe K-EDGE X-RAY ABSORPTION FINE STRUCTURE (XAFS) OF THE INTERCALATION OF LITHIUM INTO $\mathrm{FeS}_{2}$ ELECTRODES}

\section{A. BRIEF BACKGROUND}

A better understanding of the changes in the structure and electronic properties of pyrite $\left(\mathrm{FeS}_{2}\right)$ and its corresponding lithiated derivatives, (denoted generically as $\mathrm{Li}_{x} \mathrm{FeS}_{2}, 0 \leq \mathrm{x} \leq 2$ ), induced by the chemical and/or electrochemical insertion and removal of lithium ions into and from these materials is important to the further development of $\mathrm{Li}_{-\mathrm{FeS}}$ high energy, secondary batteries. 35 Considerable insight into certain aspects of this phenomenon has been gained based on recent studies involving a variety of spectroscopic and structural techniques, including infrared $36,57 \mathrm{Fe}$ Mossbaut effect spectroscopy (MES), 37-4I X. ray diffraction $37-39,42$ and extended $X$-ray absorption fine structure (EXAFS), 38 with much of the emphasis being focused on the identification of the reaction products of these reactions. 
The work reported herein presents in situ XAFS spectra of $\mathrm{FeS}_{2}$ before and after electrochemical insertion of one and two lithium-ion equivalents, $\left(\mathrm{Li}^{+}\right)$eq. Unlike other studies reported in the literature, these measurements were conducted in a specially designed spectroelectrochemical cell using components and electrolytes very similar to those of conventional, non-aqueous solvent, ambient temperature, primary $\mathrm{Li}_{-\mathrm{FeS}}$ batteries. Hence, the results obtained in this study are directly relevant to processes occurring in practical devices.

\section{B. EXPERIMENTAL ASPECTS}

\section{a. Spectroelectrochemical Cell}

The cell used in these experiments consists of a thin lithium anode, a separator, and a thin $\mathrm{FeS}_{2}$ cast electrode arranged in a sandwich-type configuration. This geometry provides optimal conditions for achieving a highly uniform current distribution so that the lithium incorporation (or cell discharge) will occur homogeneously over the entire $\mathrm{FeS}_{2}$ electrode. In addition, the thickness of the complete assembly, which includes a thermally-sealed, aluminized, polymer-based casing to isolate the cell components from air, was sufficiently small so as not to attenuate the $X$-ray flux appreciably. This made it possible to acquire in situ XAFS spectra in the transmission mode in a rather straightforward fashion. However, the thickness of the pyrite cast electrode in terms of absorption lengths $\left(\mu_{X}=4.6\right)$ was much larger than the ideal absorber thickness ( $\left.\mu_{\mathrm{X}} \mathrm{ca}, 1\right)$ for Fe K-edge XAFS. Consequently, thickness effect artifacts, 43 such as amplitude distortions, 44 were unavoidable in these initial measurements; hence, caution must be exercised when comparing the data presented herein with that obtained for the same (or similar) materials involving different values of $\mu_{X}$. Nevertheless, the fact that the absorber thickness (total anount of $\mathrm{Fe}$ in the beam) was kept constant throughout the course of experimentation facilitates the direct comparison of structural parameters of pristine $\mathrm{FeS}_{2}$ (in the electrode) with those for the corresponding lithiated materials generated in situ.

\section{b. Electrochemical Measurements;}

In situ XAFS spectra were collected for cells which had been discharged to depths equivalent to the insertion of one and two moles of lithium per mole of $\mathrm{FeS}_{2}$. During discharge, the cells were compressed with a C-clamp (which was removed prior to spectral acquisition) to decrease both electronic (by promoting particle-particle contact) and ionic contributions to the IR drop. Throughout this procedure, the electrodes are always in contact with the electrolyte and current collectors; hence, the integrity of the cell, and therefore the in situ character of the measurements is never compromised.

The discharge was effected using a Pine potentiostat working in the galvanostatic mode while monitoring the cell potential. The current densities involved in the discharge were small, on the order of 0.5 to 2 $\mathrm{mA} / \mathrm{cm}^{2}$ in order to avoid high electrode polarization. As a result, periods of over two hours were required to complete each one-electron discharge step ( $8.89 \mathrm{~mA}$ h capacity; $1.4 \mathrm{InA}$ current). All of the cells were assembled a few days before shipment to the synchrotron facilities and discharged immediately prior to the XAFs experiments. 


\section{c. XAFS Measurements}

XAFS data were acquired at the National Synchrotron Light Source (NSLS) at Brookhaven National Laboratory (Beamlines X18B, Current: 110 $220 \mathrm{~mA}$; energy: $2.5 \mathrm{GeV}$, monochronator crystal: Si<220>; step size: $0.77 \mathrm{eV}$ (XANES), $0.05 \mathrm{~A}^{-1}$ (EXAFS) and at the Stanford synchrotron Radiation Laboratory (SSRL) (Beamline VI-2, Current: 20-40 mA, Monochromator Crystal Si<111>; Step Size: $0.23 \mathrm{eV}$ (XANES), $0.05 \mathrm{~A}^{-1}$ (EXAFS)).

\section{RESULTS}

The cell discharge curves, both as a function of time and charge, are shown in Panels A and B, Fig. 6, respectively. Also indicated in this figure are the precise times at which the XAFS spectra were collected. During the insertion of the two $\left(\mathrm{Li}^{+}\right)$eq $(32.2 \mathrm{C} /$ electron), the cell voltage dropped by only $-0.4 \mathrm{~V}$, reaching $\sim 1.0 \mathrm{~V}$.

The in situ $k^{3}$-weighted EXAFS spectra, obtained after zero, one and two electron discharge steps (see curves a through $c$ in Fig. 7 , respectively) reveal a gradual loss in the fine structure as the amount of lithium in the $\mathrm{FeS}_{2}$ is increased. These changes can be better visualized in the corresponding phase-shift-uncorrected Fourier transforms (FT) shown in curves a through $\mathrm{c}, \mathrm{Fig} .8$. As indicated, the $\mathrm{FeS}_{2}$ electrode before lithium insertion (Curve a) displays features characteristic of pyrite, including pronounced peaks at 1.8 and $2.9 \AA$, attributable to the first two Fe-S shells (both with coordination number $N=6$ ) and also at ca. $3.4,5$ and $6 \dot{A}$ assigned to the first three $\mathrm{Fe}-\mathrm{Fe}$ shells in the lattice $(N=12,6$ and 24 , respectively). After the insertion of one and two $\left(\mathrm{Li}^{+}\right)_{\mathrm{eq}}$, the intensities of the shells with $\mathrm{r}^{\prime}>2.5 \AA$ decreased monotonically compared to the major Fe-S peak.

A curve fitting analysis of the Fourier-filtered Fe-S backscattering $\left(k^{3} v(k)\right)$ for the $\mathrm{FeS}_{2}$ electrode before and after insertion of one and two $\left(\mathrm{Li}^{+}\right)_{\text {eq }}$ was performed with $\mathrm{Fe}-\mathrm{S}$ phase and ainplitude functions extracted from the first ( $\mathrm{Fe}-\mathrm{S}$ ) backscattering in $\mathrm{FeS}_{2}$. The resulting Fe-S interatomic distances, $d(\mathrm{Fe}-\mathrm{S})$, for $\mathrm{FeS}_{2}$ after lithium insertion, i.e. $2.27+/-0.02$ and $2.29+/-0.02 \AA$, for one and two $\left(\mathrm{Li}^{+}\right)$egl respectively, are significantly shorter than those reported for $\mathrm{Li}_{2} \mathrm{FeS}_{2}, 42$ namely, $2.3737(7)$ and $2.4126(15)$ $\AA$, but very close to that for pyrite, for which $d($ Fe-S $)=2.250+/-0.005$ $\AA .45$ For bulk powder specïnens of $\mathrm{Li}_{x} \mathrm{FeS}_{2}$ deintercalated materials $0.21<\mathrm{x}$ $<2.0$, Brec et al. reported Fe-S distances (based on EXAFS measurements) in the range $2.28-2.33 \AA$. These distances are consistent with those found in this work. $3 \dot{8}$

Compelling evidence that the material produced by the insertion of two $\left(\mathrm{Li}^{+}\right)$eq into $\mathrm{FeS}_{2}$ is not crystalline $\mathrm{Li}_{2} \mathrm{FeS}_{2}$ has been obtained from in situ room temperature $57 \mathrm{Fe}$ Mossbauer effect spectroscopy (MES) measurements using a spectroelectrochenic l cell of similar design to that described here. $46^{\circ}$ According to these in situ data, the isomer shift $(\delta)$ of the single doublet spectrum, $0.30 \mathrm{~mm} / \mathrm{s}$ vs. $\alpha-\mathrm{Fe}$ at room temperature, for the di-lithiated material is substantially different from those of the two doublets observed for crystalline $\mathrm{Li}_{2} \mathrm{FeS}_{2}$ in this $\left(\delta_{1}=0.47, \Delta_{1}=1.59 ; \delta_{2}\right.$ $\left.=0.47, \Delta_{2}=0.62 \mathrm{~mm} / \mathrm{s}\right)^{46}$ and other laboratories. 47 It interesting to note that the presence of two doublets in the MES spectra of this material 
appcars to be attributed to occupational disorder between fron and lithium at the tetrahedral sites. 38

The reduction in the $S$ and Fe backscattering amplitudes upon incorporating $\mathrm{Li}^{+}$into $\mathrm{FeS}_{2}$ can be explained on the basis of at least three different models:

1) loss of forward focusing (or net decrease in the electronic overlap between the absorbing atom and the backscattering atoms) upon changing the octahedral geometry surrounding iron in $\mathrm{FeS}_{2}$.

11) loss of coherency of the EXAFS signal due to the presence of a broad distribution of $d(\mathrm{Fe}-\mathrm{S})$ and $d(\mathrm{Fe}-\mathrm{Fe})$ values in the lithiated phase. This is to be contrasted with the narrow distribution of $u(F e-S)$ and $\mathrm{d}(\mathrm{Fe}-\mathrm{Fe})$ for highly crystalline pyrite.

1i1) phase cancellation effects between Fe-S and Fe-Fe interactions, similar to the behavior observed for $\mathrm{Fe}-\mathrm{Fe}$ and $\mathrm{Fe}-\mathrm{Mo}$ interactions in $\mathrm{MoFe}_{3} \mathrm{~S}_{4}$ clusters. 48

The most probable structure of the electrochemically formed material involves a highly disordered (possibly amorphous) form of $\mathrm{Fe}_{1-\mathrm{x}} \mathrm{S}$ (with $\mathrm{Li}^{+}$ counterbalancing the charge). Support for this view is provided by the similarity between the values $\delta$ and $\Delta$ of crystalline $\mathrm{FeS}_{2}(\delta=0.313+/$. $0.008 \mathrm{~mm} / \mathrm{s} ; \Delta 0.611+/ .0 .003 \mathrm{~mm} / \mathrm{s}$ ) 49 and fine (or superparamagnetic) particles of $\mathrm{Fe}_{1-\mathrm{x}} \mathrm{S}(\delta=0.27 \cdot 0.30 \mathrm{~mm} / \mathrm{s} ; \Delta 0.54-0.77 \mathrm{~mm} / \mathrm{s})$ in one study, 50 and $\delta=(0.36+/-0.03) \mathrm{mm} / \mathrm{s} ; \Delta=(0.65+/-0.03) \mathrm{mm} / \mathrm{s}$ in another. 51 This observation is consistent with the fact that the in situ room temperature MES spectra of $\mathrm{FeS}_{2}$ obtained for batteries of the type used in this work appears to be independent of the extent of $\mathrm{Li}^{+}$insertion up to the insertion of two $\left(\mathrm{Li}^{+}\right)_{\mathrm{eq}}$. ${ }^{4} \mathrm{~b}$

Additional support for $F+1-x^{S}$ as the most probable reaction product is provided by the XANES spectra of the three specimens examined, shown in Fig. 9. Despite the much decreased resolution of the otherwise highly structured near edge region of crystalline pyrite 52 caused by the thick nature of the specimen (vide supra), the insertion of $\mathrm{Li}^{+}$into the lattice leads, in addition to a much steeper edge jump, to a rounding of the XANES region. Such lack of fine structure has been found in NiAs-type $\mathrm{Fe}_{1-\mathrm{x}} \mathrm{S}^{53}$ and ascribed to a shift in the position of the (fine) structure toward lower energies induced by an increase in the metal-ligand distance. The same phenomenon has been observed for $\mathrm{CuS}^{54}$ and explained in terms of the complexity of the crystal structure where Cu atoms often occupy various types of low symmetry sites. Also noteworthy, is the overall shift of the XANES toward lower energies as the anount of $\mathrm{Li}^{+}$in the lattice is increased, an effect that is consistent with the gradual (electrochemical) reduction of the iron centers.

It is expected that more detajled studies of the type reported here may provide much needed insight into the general phenomenon of lithium ion insertion and de-insertion and shed light on the nature of the processes responsible for the lacl: of electrochenical reversibility of ambient temperature, non-aqueous elcetrolyte Li-FeS 2 cells. 


\section{FIGURE CAPTIONS}

Figure 1. Cyclic voltanmetry curves obtained with a two-electrode cell (solid curve, electrode area: $0.27 \mathrm{~cm}^{2}$ ) and a three-electrode cell (dashed curve, electrode area: $0.20 \mathrm{~cm}^{2}$ ) for $\mathrm{PEO}-\mathrm{LiClO}_{4}-\mathrm{PC}$ films. For the three-electrode experiment, the zero point was shifted positive by $0.3 \mathrm{~V}$ to facilitate the comparison of the curves.

Figure 2. Cyclic voltammetry showing lithium bulk deposition and stripping on a ca. $2000 \AA$ gold electrode with a PEO- $\mathrm{LiClO}_{4}$ film (ca. 60 um thick, $36 \mathrm{CH}_{2} \mathrm{O} / \mathrm{Li}^{-1}$ ). Temperature ( $\left.\mathrm{T}\right): 48^{\circ} \mathrm{C}$ : Sweep rate $(v): 5$ $\mathrm{mV} / \mathrm{s}$; Electrode area (A): $2.20 \mathrm{~cm}^{2}$. The Li foil counter electrode was also used as the reference. Upper curves: cycles 1 to 4 ; Lower curves: cycles 24 to 26.

Figure 3. Duplicate cyclic voltanmetric sweeps (first negative-going cycle to $-0.8 \mathrm{~V}$ vs. Li counter electrode) for two different experimental runs with $\mathrm{PEO}-\mathrm{LiClO}_{4}$ films (ca. $60 \mu \mathrm{m}$ thick, 0.27 $\mathrm{cm}^{2}$ area, $36 \mathrm{CH}_{2} \mathrm{O} / \mathrm{Li}^{+}$), with a gold working electrode (ca. 2000 $\AA$ sputtered on glass). $\quad \mathrm{T}=55^{\circ} \mathrm{C} ; \quad v=5 \mathrm{mV} / \mathrm{s}$; Initial open circuit potentials (IOCP) : $2.85 \mathrm{~V}$ and $2.84 \mathrm{~V}$ for the solid and dashed curves, respectively.

Figure 4. Wide potential range cyclic voltametry showing lithium bulk deposition and stripping on a ca. $2000 \AA$ gold electrode (sputtered on glass) with a $\mathrm{PEO}-\mathrm{LiClO}_{4}$ film (ca. $60 \mu \mathrm{m}$ thick, 36 $\left.\mathrm{CH}_{2} \mathrm{O} / \mathrm{Li}^{+}\right) . \mathrm{T}=55^{\circ} \mathrm{C} ; \quad v=5 \mathrm{mV} / \mathrm{s} ; \quad \mathrm{A}=0.27 \mathrm{~cm}^{2} ; \quad$ IOCP $=1.6 \mathrm{~V}$ vs. $\mathrm{Li}_{\mathrm{Li}}{ }^{+}$(separate reference electrode using $\mathrm{Li}$ electrodeposited on $\mathrm{Au}$ ).

Figure 5. In situ ATR-FTIR spectra for a PEO-LiClO 4 film (ca. $60 \mu \mathrm{m}$ thick, $36 \mathrm{CH}_{2} \mathrm{O} / \mathrm{Li}^{+}$) at $48^{\circ} \mathrm{C}$, ubtained after sweeping the potential from $2.0 \mathrm{~V}$ vs. Li to $0.5 \mathrm{~V}$ at $5 \mathrm{mV} / \mathrm{s}$ and holding the potential at that point (Curve a) after subsequently sweeping the potential from $2.0 \mathrm{~V}$ to $0.0 \mathrm{~V}$ and opening the circuit (settling at ca. 0.3 $\mathrm{V}$ (curve b) and after siveeping the potential from $2.0 \mathrm{~V}$ to -0.5 $\mathrm{V}$ and opening the circuit (settling at ca. $0.4 \mathrm{~V}$ ). The reference spectrum was obtained for the cell at $2.0 \mathrm{~V}$ (near the IOCP) before applying an external potential to the cell.

Figure 6. Cell discharge curves as a function of time, A and charge, B. The precise times at which the XAFS spectra were collected are indicated in $B$.

Figure 7. In situ $\mathrm{k}^{3}$-weighted EXAFS spectra obtained during the various stages of discharge, Zero (Curve a), 1 (Curve b) and 2 (Curve c) electron-discharge.

Figure 8. Fourier transforins for the stages of discharge specified in the caption for Fig. 6 .

Figure 9. XANES for the stages of discharge specified in the caption for Fig. 6 . 


\section{V, REFERENCES}

1. McLarnon, F. R.; Cairns, E. J. Ann. Rev. Energy. 1989, 14, 241.

2. Contour, J. P.; Salesse, A.; Froment, M.; Garreau, M.; Thevenin, J.; Warin, D. Microsc. Spectrosc. Electron. 1979, 4, 483-491.

3. Hoenigman, J. R.; Keil, R. G.; Wittberg, T. N.; Peters, J. A. Vide, Couches Minces 1980, 201 (Supp1., Proc. Int. Vac. Congr., 8th, V2) 494-497.

4. Povarov, Y. M.; Beketaeva, L. A.; Astakhov, I. I.; Surikov, V. V. Electrokhiniya, 1980, 16(11), 1768-1772.

5. Yen, S. P. S.; Shen, D.; Vasquez, R. P.; Grunthaner, F. J.; Somoano, R. B. J. Electrochem. Soc., 1981, 128(7), 1434 .

6. Povarov, Y. M.; Beketaeva, L. A. ; Astakhov, I. I.; Surikov, V. V.; Moshtev, R.; Puresheva, B. Electrokhimiya. 1982, 18(9), 1160-1169.

7. Kilroy, W. P.; Anderson, C. R. J. Power Sources, 1983, 9, 387-407.

8. Hoenigman, J. R.; Keil, R. G. App. Surf. Sci. 1984, 18, 207-222.

10. Nazri, G.; Muller, R. H. J. Electrochem. Soc., 1985, $132(9), 2050$.

11. Nebesny, K. W.; Armstrong, N. R. J. Vac. Sci. Techno1. A, 1985, 3(4), 1763.

12. Schwager, F.; Geronov, Y.; Mull↔r, R. H.J. Electrochem. Soc. 1985, 132(2), 285

13. Thevenin, J. J. Power Sources, 1985, 14, 45-52.

13. Anderson, M. Spectroscopy, 1987, 2(2), 54.

14. Aurbach, D.; Daroux, M. L.; Faguy, P. W.; Yeager, E. J. Electrochem. Soc. 1987, 134(7), 1611.

15. Kazarinov, V. E.; Bagotzky, V. S. J. Power Sources, 1987, 20, 259-263.

16. Thevenin, J. G.; Muller, R. H. J. Electrochem. Soc. 1987, 34(2), 273.

17. Aurbach, D.; Gottlieb, H. Electrochim. Acta 1989, 34(2), 141-156.

18. Aurbach, D. J. Electrochem. Soc. 1989, 136(4), 906.

19. Aurbach, D.; Gofer, Y.; Langzall, J. J. Electrochem. Soc. 1989, 136, $3198-3205$.

20. Aurbach, D.; Youngman, 0.; Gofer, Y.; Meitav, A. Electrochim. Acta $1990,35,625-638$.

21. Aurbach, D.; Youngman, O.; Dan, P. Electrochim. Acta 1990, 35, 639-655.

22. Aurbach, D.; Daroux, M.; Faguy, P.; Yeager, E. J. Electroanal. Chem. $1991,297,225-244$.

23. Goshen, E.; Chusid (Youngnian) 0.; Aurbach, D. J. Electrochem. Soc. 1991, 138, L6-L9.

24. Aurbach, D.; Gofer, Y.; Ben-Zion, M.; Aped, P. J. Electroanal. Chem. $1992,339,451-471$.

25. Aurbach, D.; Zaban, A. J. Electroanal. Chem. 1993, 348, 155-179.

26. Hunter, C. C.; Sinclair, D. C.; West, A. R.; Hooper, A. J. Power Sources, $1988,24,157-164$.

27. Scrosati, B.; Selvaggi, A.; Croce, F.; Gang, W. J. Power Sources 1988, 24, 287 294.

28. Nazri, G. A.; Meibuhr, S. G. J. Electrochem. Soc. 1989, 136, 2450-2454.

29. Harvey, P. E. J. Power Sources 1989, 26, 23-32.

30. Croce, F.; Capuano, A.; Selvaggi, B.; Scrosati, B. J. Power Sources $1990,32,381-388$.

31. Huq, R.; Koksbang, R.; Tonder, L. E.; Farrington, G. C. In Proceedings of the Symposium on Primary and Secondary Lithium Batteries, Abraham, $\mathrm{K}$. and Salomon, M.; Eds., The Electrochemical Society: Pennington, NJ, 1989, Pp. $154-156$.

32. Huq, R.; Farrington, G. C.: Kolssbang, R.; Tonder, P. E. Solid State Ionics $1992,57,277-283$. 
33. Ichino, T.; Cahan, B. D.; Schersun, D. A. J. Electrochem. Soc. 1991, 138, L59-L61.

34. Barbour, R.; Scherson, D. A. in Estended Abstracts, 1992-2, Abstract No. 40, pp. $56-57$ (1992).

35. a. Various monographs in the area of $\mathrm{Li} / \mathrm{FeS}_{2}$ cells may be found in Gabano, J.; Ed., Lithium Batteries, Academic Press, 1983.

b. See also, Tomczuk, 2.; Tani, B.; Otto, N. C.; Roche, M. F.; Vissers, D. R. J. Electrochem. Soc., 1982, 129, 926.

36. Gard, P.; Sourisseau, C.; Ouvrard, G.; Brec, R. Solid State Ionics 1986, 20,231 .

37. Blandeau, L.; Ouvrard, G.; Calage, Y.; Brec, R.; Rouxe1, J. J. Phys, C: Solid State Phys. 1987, 20, 4271.

38. Brec, R.; Prouzet, E.; Ouvrard, G. J. Power Sources, 1989, 26, 325.

39. Fong, R.; Jones, C. H. W.; Dahn, J. R. J. Power Sources 1989, 26, 333.

40. Fong, R.; Dahn, J. R.; Jones. C. H. W. J. Electrochem. Soc. 1989, 136, 3206 .

41. Jones, C. H. W.; Kovacs, P. E.; Sharma, R. D.; McMillan, R. S. J. Phys. Chem. 1990, 94, 832 .

42. Batchelor, R. J.; Einstein, F. W. B.; Jones, C. H. W.; Fong, R.; Dahn, J. R. Phys. Rev. B, 1988, 37, 3699.

43. a. Stern, E. A.; Kim, K. Phy's. liev. B. 1981, 23, 3781.

b. Goulon, J.; Goulon-Ginet, L.: Cortes, R.; Dubois, J. M. J. Physique, $1982,43,539$.

c. Lytle, F. W.; In Application of Synchrotron Radiation; Vo1. 4, Winick, H.; Xian, D.; Ye, M. H.; Huang, T.; Eds., Gordon and Breach: New York, 1989 , Pp. 135.

44. After-the-fact thickness effect corrections for strongly absorbing materials, such as those studied in this work, cannot always eliminate amplitude distortions. See for example: a. B. K. Teo, M. R. Antonio, B. A. Averill, J. All. Chem. Soc. 1983, 105, 3751; b. Antonio, M. R.; Song, I.; Yamada, H. J. Solid State Chem. 1991, 93, 183.

45. Finklea, S. III.; LeConte C. Acta Cryst. 1976, A32, 529.

46. Fierro, C.; Leger, V.; Akridge, J.; Scherson, D. (to be submitted).

47. See for example: Melendres, C. J. Phy's. Chem. 1978, 82, 2850

48. Antonio. M. R.; Teo, B. K.; Cleland, W. E.; Averill, B. A. J. Am. Chem. Soc. 1983, 105, 3477.

49. Evans, B. J.; Johnson, R. G.; Senftle, F. E.; Cecil, C. B.; Dulong, F. Geochimica et Cosmochimica Acta, 1982, 46, 761.

50. Hidaka, S.; Iino, A.; Nita, K.; Morinaga, K.; Yamazoe, N. Bu11. Chem. Soc. JPn. 1988, 61, 3169.

51. Vaishnava, P. P.; Montano, P. A.; Tischler, R. E.; Pollack, S. S. J. Catalysis, 1982, 78, 454 .

52. Drager, G.; Frahm, R.; Materlik, G.; Brumuer, O. Phys. Stat. Sol. 1988, $146,287$.

53. Petiau, J.; Sainctavit, Ph.: Calas, (i. Mat. Sci. Eng. B1 1988, 237.

54. Sugiura, C. J. Chem. Phy's. 1984, 30, 1047. 


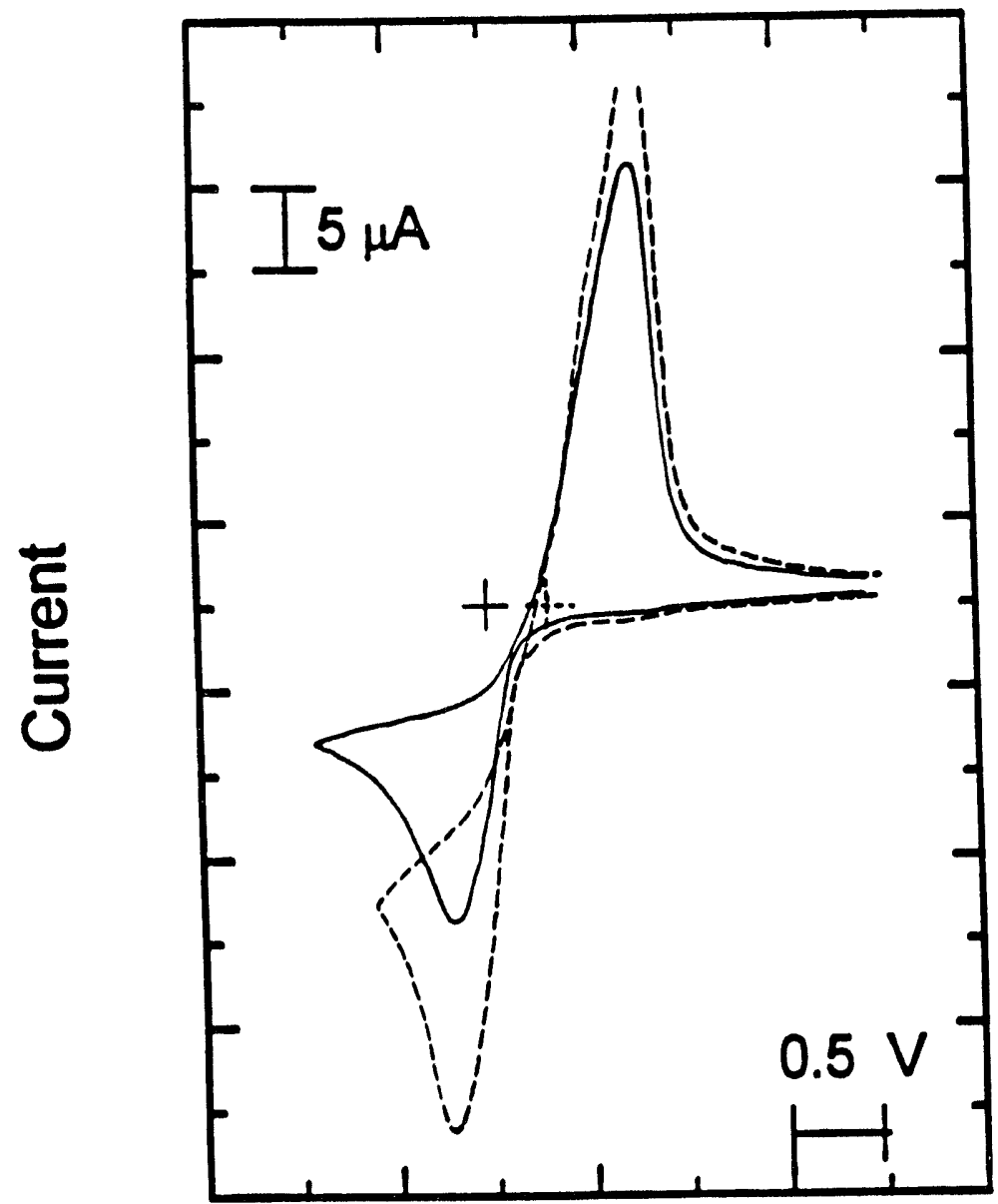

Potential, V vs. Li

Figure 1. Cyclic voltammetry curves obtained with a two-electrode cell (solid curve, electrode area: $0.27 \mathrm{~cm}^{2}$ ) and a three-electrode cell (dashed curve, electrode area: $0.20 \mathrm{~cm}^{2}$ ) for $\mathrm{PEO}-\mathrm{LiClO}_{4}-\mathrm{PC}$ films. For the three-electrode experiment, the zero point was shifted positive by $0.3 \mathrm{~V}$ to facilitate the comparison of the curves. 


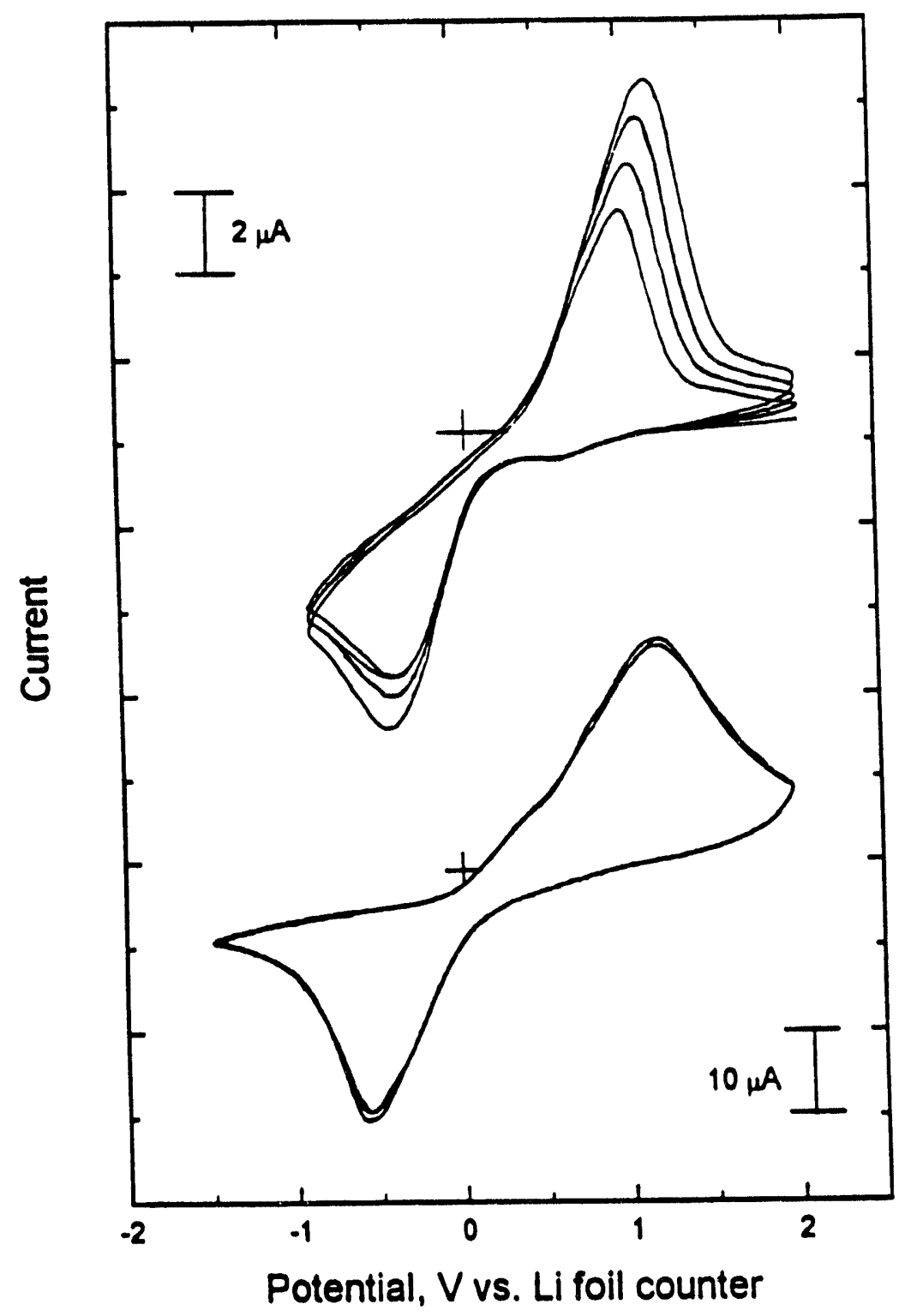

Figure 2. Cyclic voltammetry showing lithium bulk deposition and stripping on a ca. $2000 \AA$ gold electrode with a PEO- $\mathrm{LiClO}_{4}$ film (ca. $60 \mu \mathrm{m}$ thick, 36 $\mathrm{CH}_{2} \mathrm{O} / \mathrm{Li}^{+}$). Temperature (T): $48^{\circ} \mathrm{C}$ : Sweep rate $(\mathrm{v}): 5 \mathrm{mV} / \mathrm{s}$; Electrode area $(\AA): 2.20 \mathrm{~cm}^{2}$. The $\mathrm{Li}$ foil counter electrode was also used as the reference. Panel a: cycles 1 to 4; Panel b: cycles 24 to 26. 


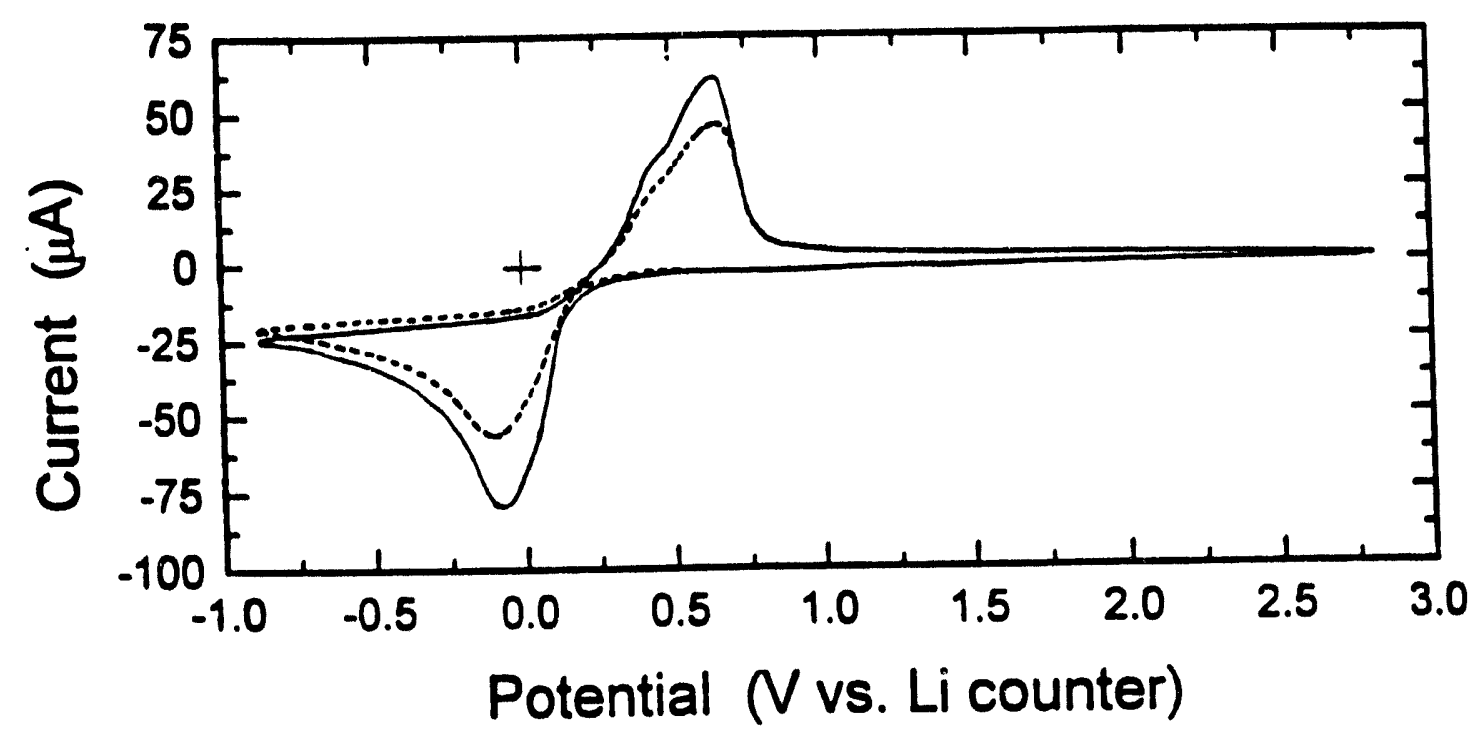

Figure 3. Duplicate cyclic voltammetric sweeps (first negative-going cycle to $-0.8 \mathrm{~V}$ vs. $\mathrm{Li}$ counter electrode) for two different experimental runs with $\mathrm{PEO}-\mathrm{LiClO}_{4}$ films (ca. $60 \mu \mathrm{m}$ thick, $0.27 \mathrm{~cm}^{2}$ area, $36 \mathrm{CH}_{2} \mathrm{O} / \mathrm{Li}^{+}$), with a gold working electrode (ca. $2000 \AA$ sputtered on glass). $\mathrm{T}=55^{\circ} \mathrm{C} ; v=5 \mathrm{mV} / \mathrm{s}$; Initial open circuit potentials (IOCP) : $2.85 \mathrm{~V}$ and $2.84 \mathrm{~V}$ for the solid and dashed curves, respectively. 


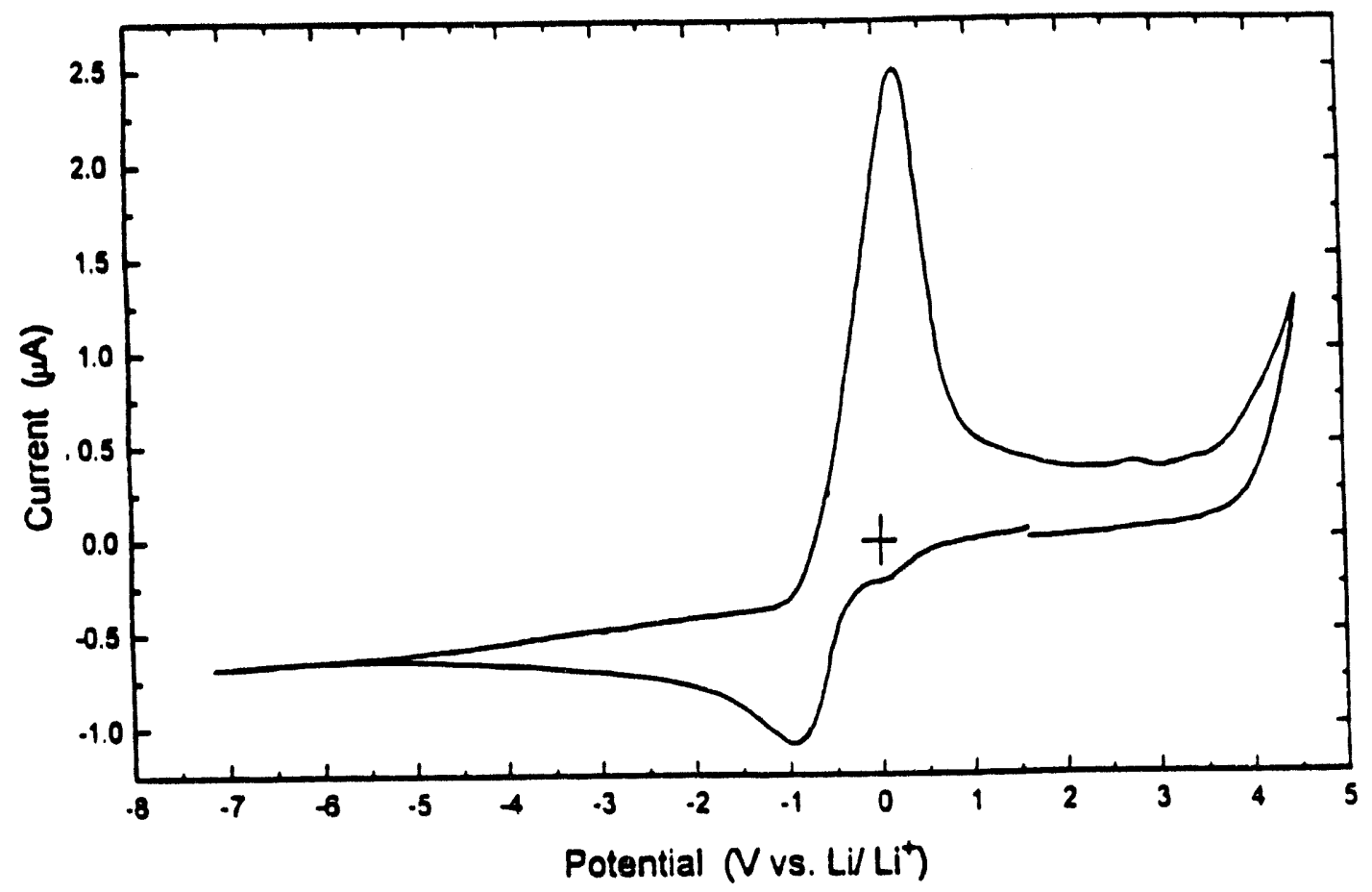

Figure 4. Wide potential range cyclic voltammetry showing lithium bulk deposition and stripping on a ca. $2000 \AA$ gold electrode (sputtered on glass) with a PEO$\mathrm{LiClO}_{4}$ film (ca. $60 \mu \mathrm{m}$ thick, $36 \mathrm{CH}_{2} \mathrm{O} / \mathrm{Li}^{+}$). $\mathrm{T}=55^{\circ} \mathrm{C} ; v=5 \mathrm{mV} / \mathrm{s} ; \mathrm{A}$ $=0.27 \mathrm{~cm}^{2} ; \quad$ IOCP $=1.6 \mathrm{~V}$ vs. $\mathrm{Li} / \mathrm{Li}+$ (separate reference electrode using $\mathrm{Li}$ electrodeposited on $\mathrm{Au}$ ). 


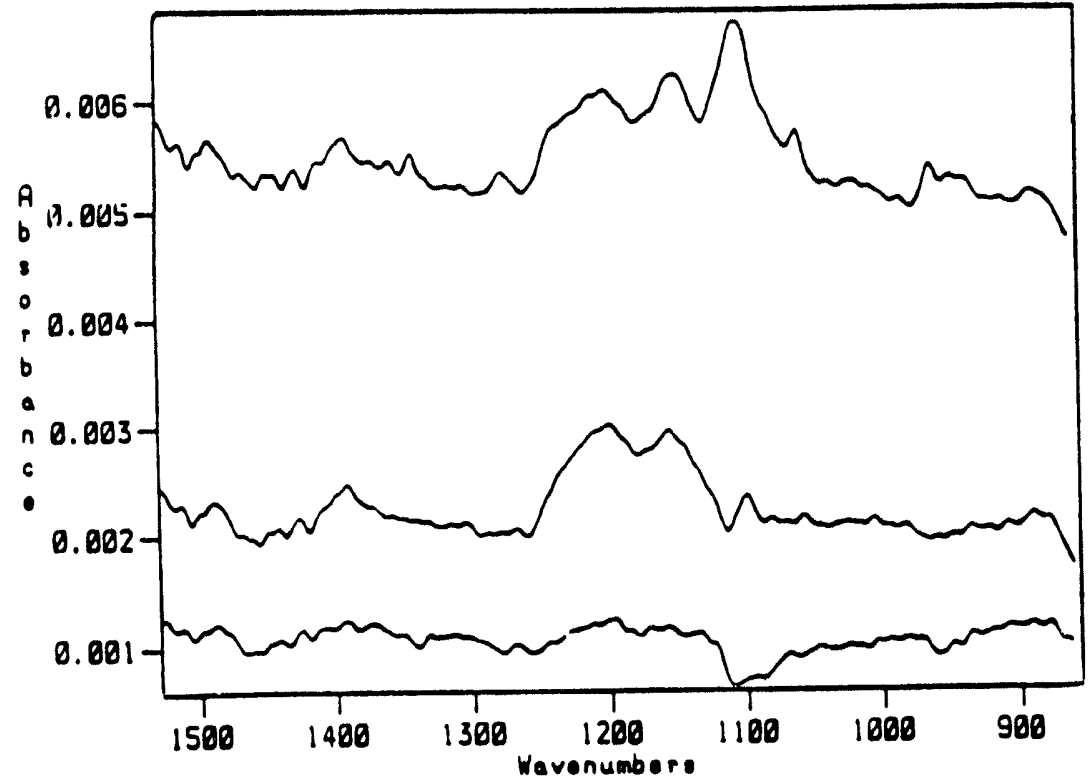

Figure 5. In situ ATR-FTIR spectra for a PEO-LiClO 4 film (ca. $60 \mu \mathrm{m}$ thick, 36 $\mathrm{CH}_{2} \mathrm{O} / \mathrm{Li}^{+}$) at $48^{\circ} \mathrm{C}$, obtained after sweeping the potential from $2.0 \mathrm{~V}$ vs. $\mathrm{Li}$ to $0.5 \mathrm{~V}$ at $5 \mathrm{mV} / \mathrm{s}$ and holding the potential at that point (Curve a) after subsequently sweeping the potential from $2.0 \mathrm{~V}$ to $0.0 \mathrm{~V}$ and opening the circuit (settling at ca. $0.3 \mathrm{~V}$ (curve b) and after sweeping the potential from $2.0 \mathrm{~V}$ to $-0.5 \mathrm{~V}$ and opening the circuit (settling at ca. $0.4 \mathrm{~V}$ ). The reference spectrum was obtained for the cell at $2.0 \mathrm{~V}$ (near the IOCP) before applying an external potential to the cell. 

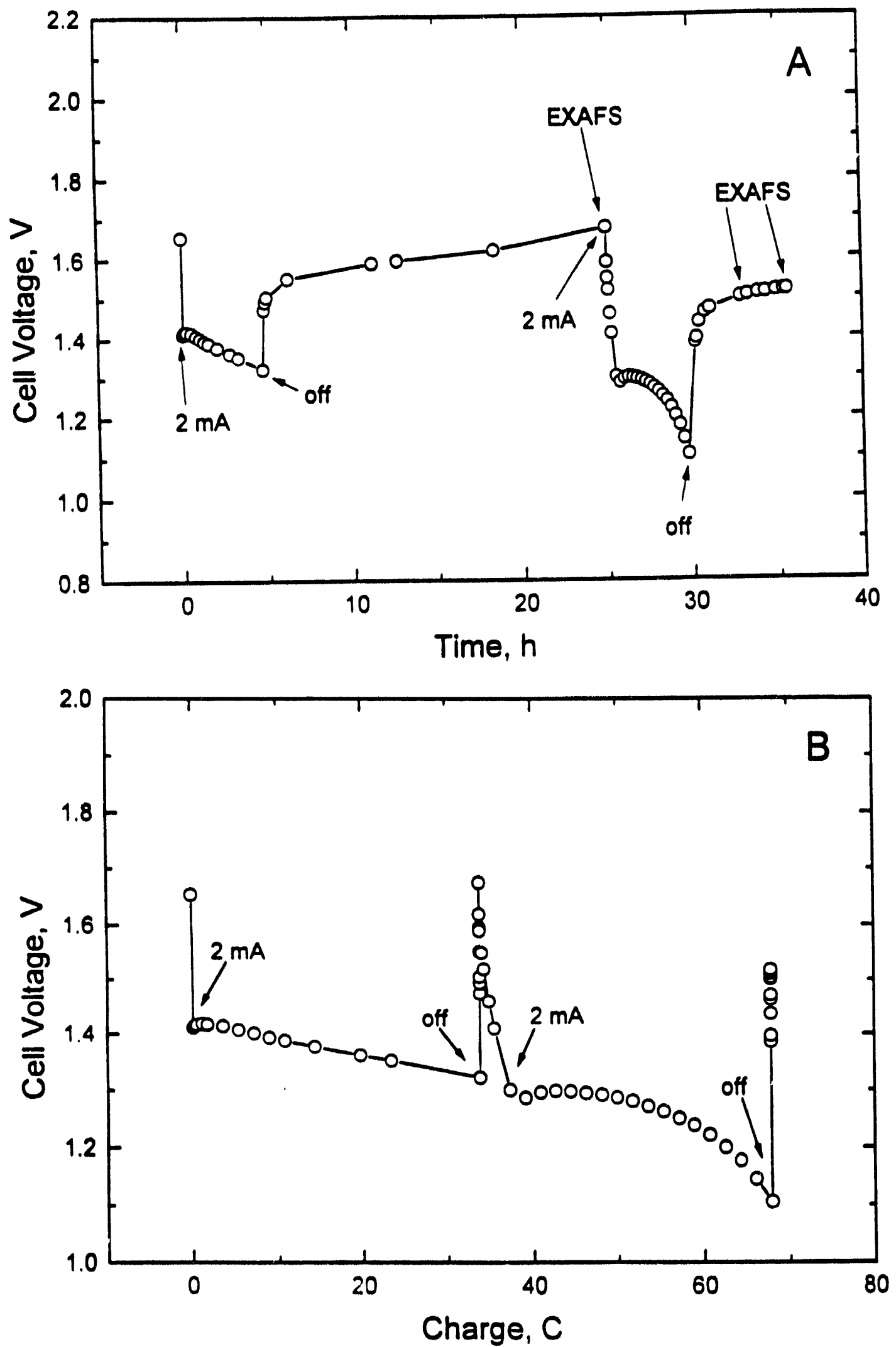

Figure 6. Cell discharge curves as a function of time, $A$ and charge, $B$. The precise times at which the XAFS spectra were collected are indicated in B. 


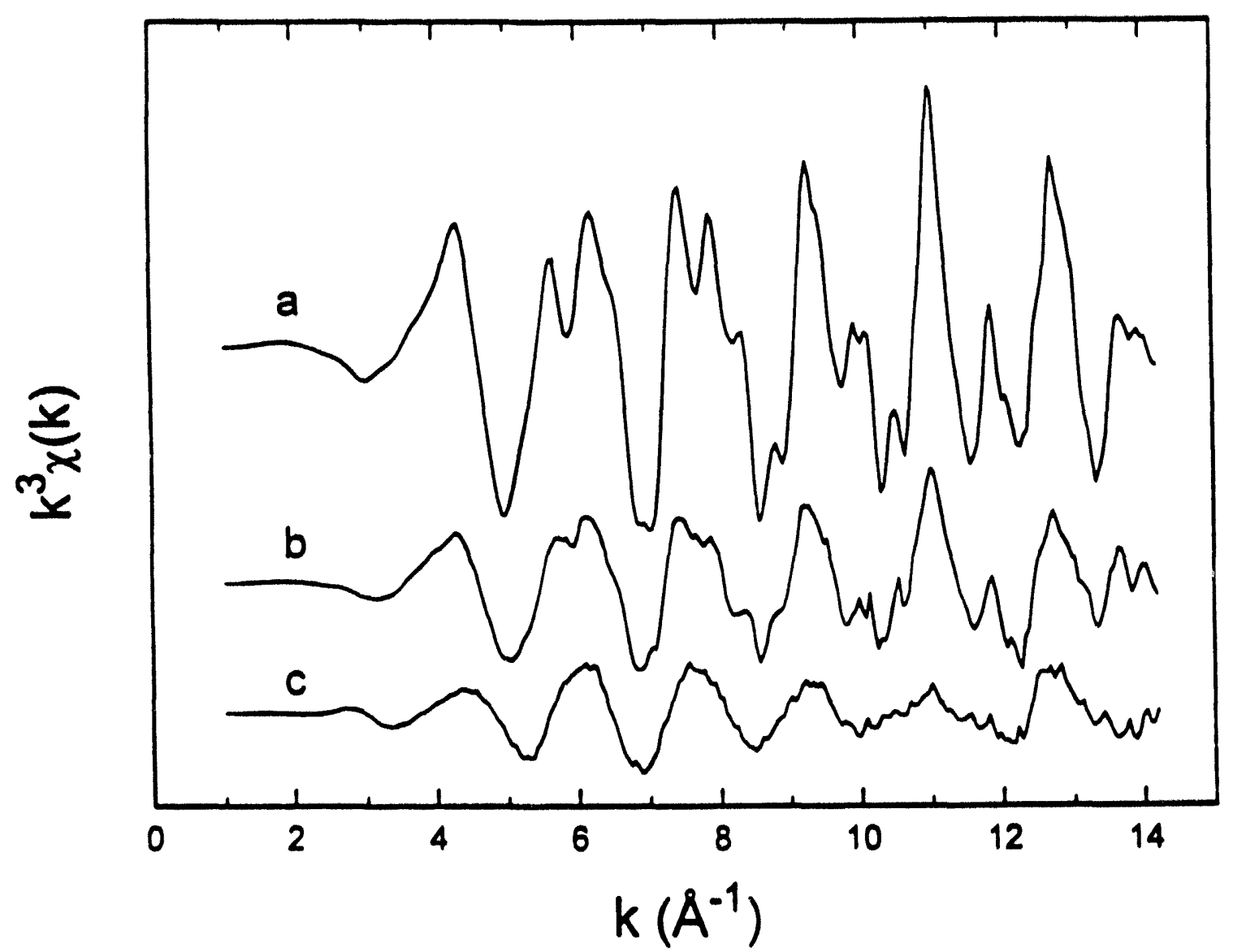

Figure 7. In situ $\mathrm{k}^{3}$-weighted EXAFS spectra obtained during the various stages of discharge, Zero (Curve a), 1 (Curve b) and 2 (Curve c) electron-discharge. 


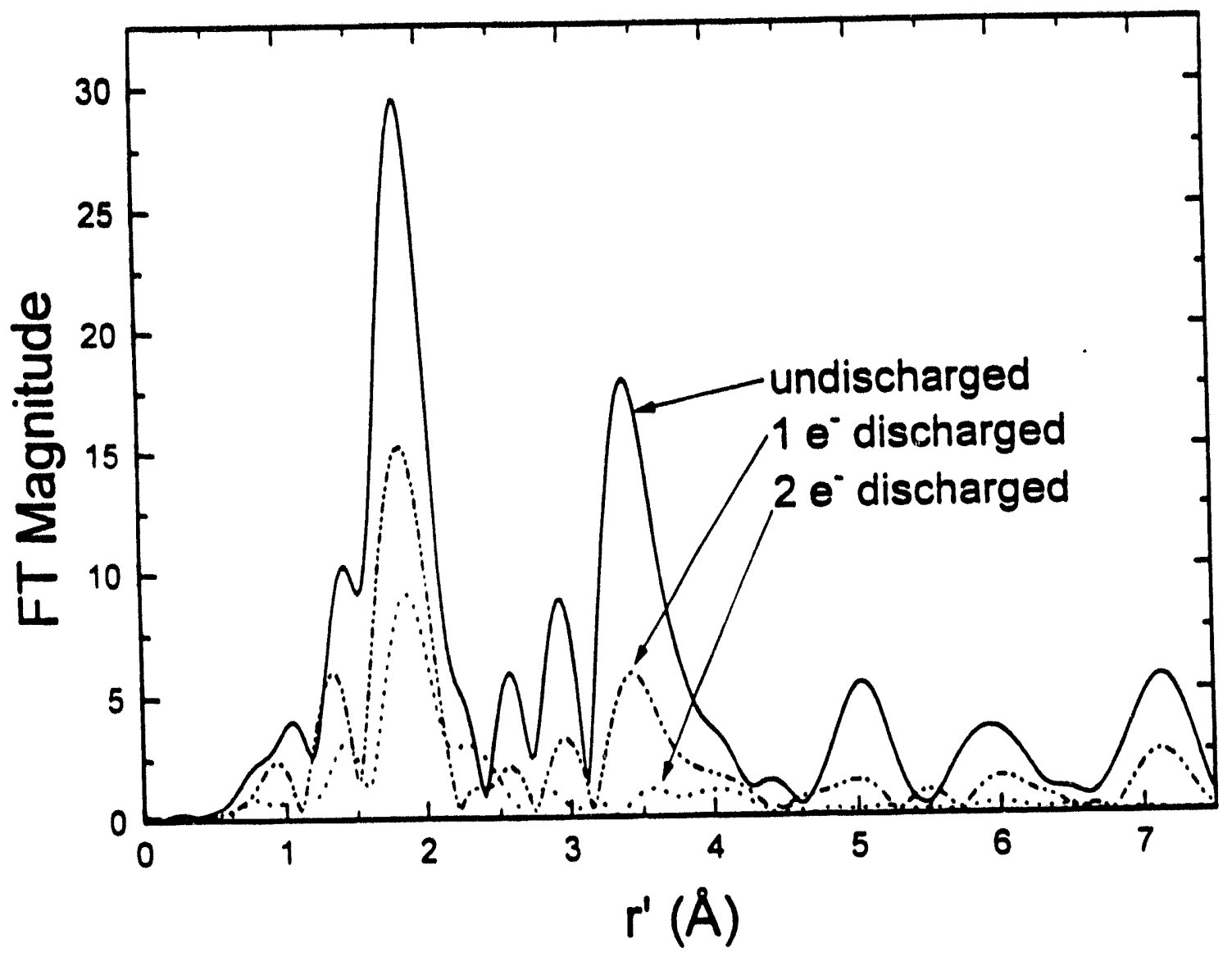

Figure 8. Fourier transforms for the stages of discharge specified in the caption for Fig. 6. 


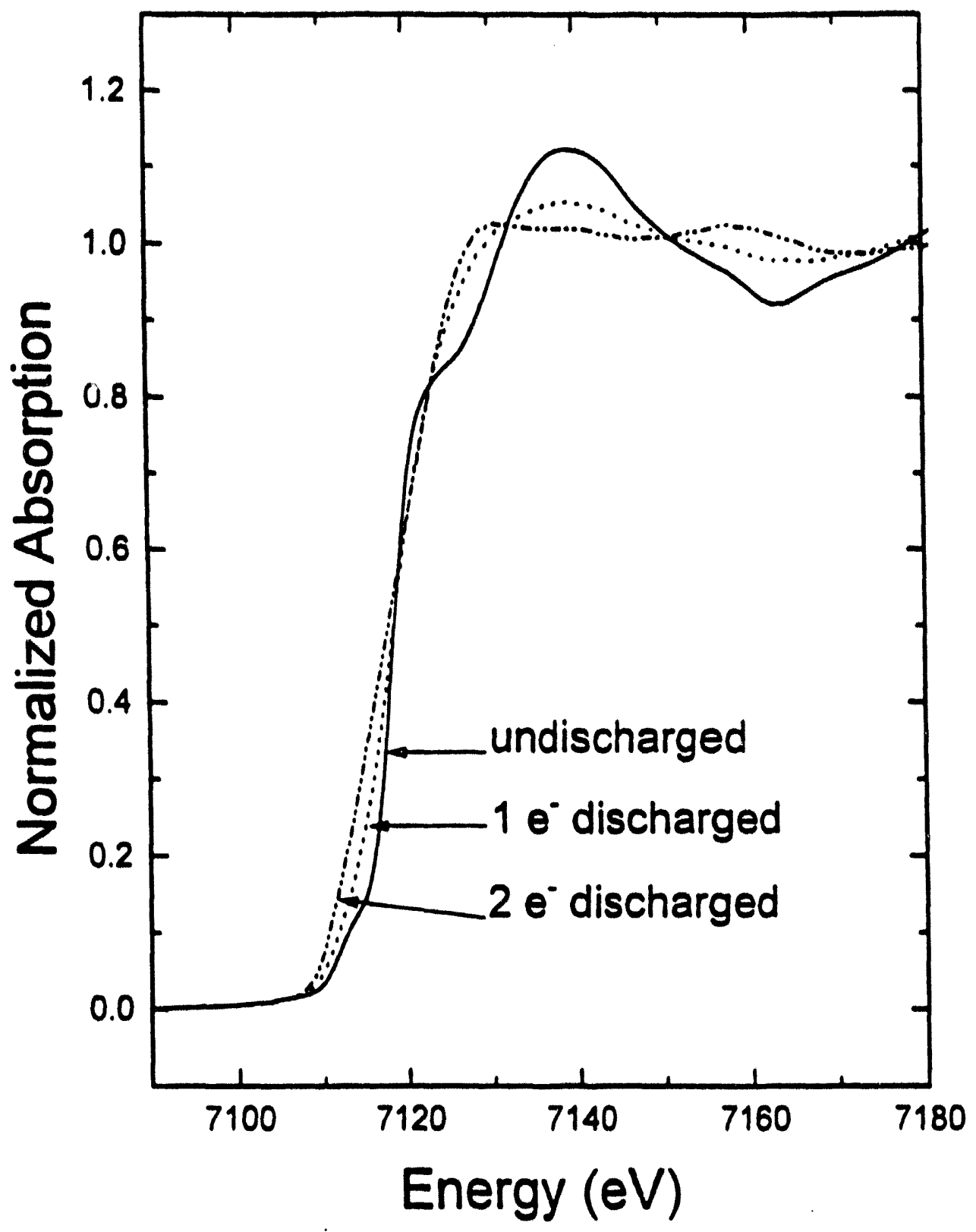

Figure 9. XANES for the stages of discharge specified in the caption for Fig. 6 . 

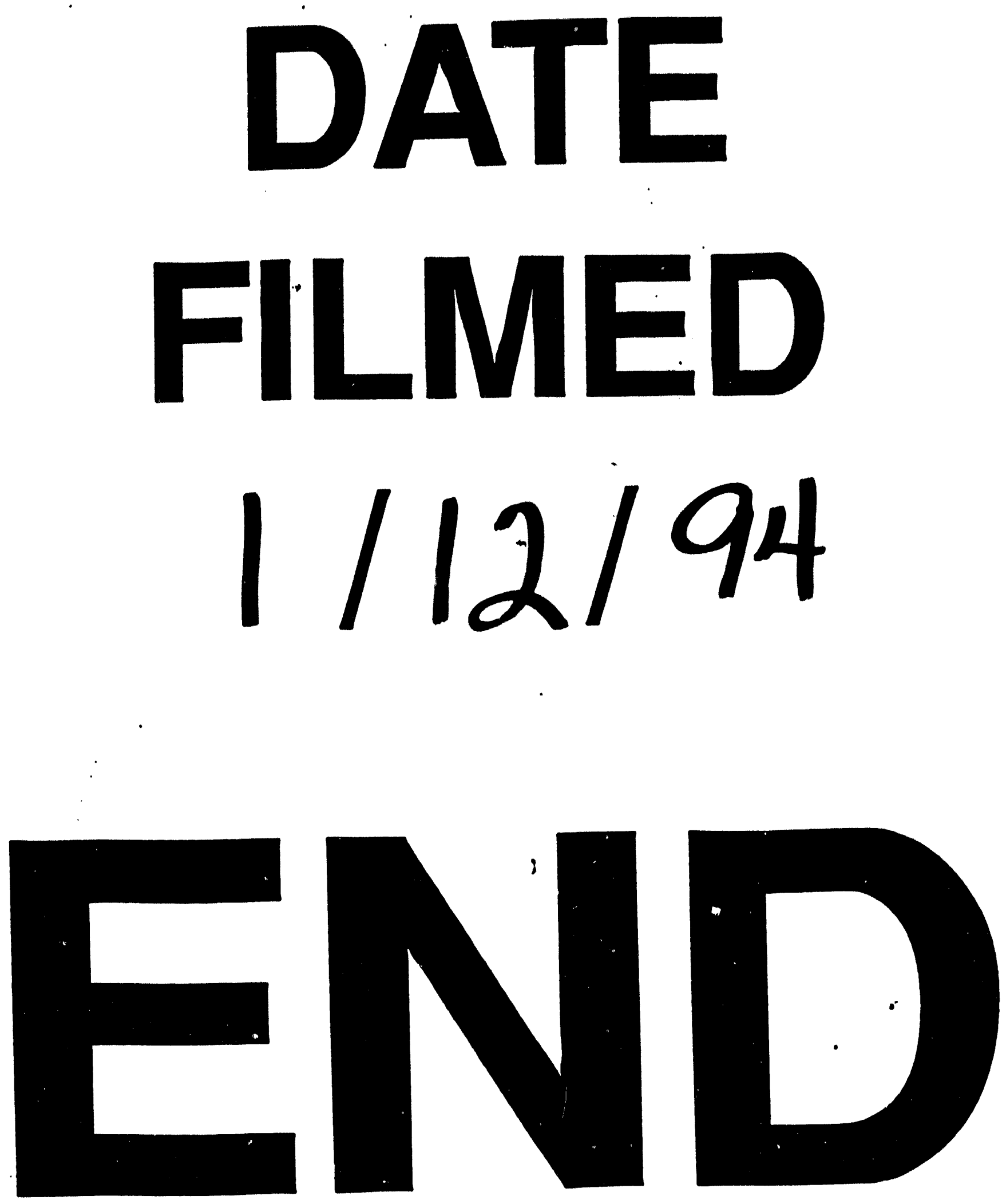
